\title{
THE ISLAMIC INFLUENCE ON BUILT ENVIRONMENT IN ANCIENT ISLAMIC CITIES: A DESCRIPTIVE-ANALYTIC STUDY
}

\author{
Ziad M. M. Shehada*
}

\begin{abstract}
A built environment is considered to be the 'physical face' of a civilization. Accordingly, scientists studying an ancient civilization often refer to the remains of a civilization's-built heritage in order to better understand its cultural system. This has been evident in ancient Islamic cities such as Baghdad, Al-Medina, Fez, Kairouan, Marrakech, and Granada, as these cities have been well-framed, both legally and systematically. This Islamic frame is referred to as the Islamic Fiqh, and it has been accompanied by developments in urban Islamic communities. This research aims to examine the impact of Figh AlMaliki on the built environment, and the possibility of investing Fiqh to establish tourist guidance based on scientific interpretation derived from legal and cultural systems. The researcher adopted a descriptive-analytic methodology to analyze the Fuqaha' opinions, as well as to understand the relationship between Islamic architecture and Islamic Fiqh. It was found that Fiqh Al-Maliki contributed toward the formation of Islamic cities through the framed legal system. This Fiqh and historic wealth can be beneficial to realize the first image of the built environment and maintain its original form.
\end{abstract}

Keywords: Fiqh Al-Maliki, built environment, Islamic civilization, Shari'ah, architecture

\section{Introduction}

There are four Madhhab (schools) of Islamic Fiqh (Jurisprudence), namely Hanafi, Maliki, Shafi 'i, and Hanbali. ${ }^{1}$ Fiqh Al-Maliki was founded by Imam Malik bin Anas in the eighth century. The Maliki school differs slightly from the three other schools of Islamic Figh, most notably in the sources it uses to derive rulings. ${ }^{2}$ The opinions of the Fuqaha' had an obvious and considerable influence on both the Sultan and the general public. Therefore, the Fatwas issued by the Fuqaha' acted as laws or legislations on which people relied upon. ${ }^{3}$

The Fuqaha' were interested in the building provisions. They developed a science known as "the science of building contracts," which later became a standalone subject. ${ }^{4}$ It was defined as the science of building conditions, mechanisms of protection, and methods of improvements such as building secure forts, setting up gorgeous houses, constructing aqueducts, splitting the rivers using canal technology, closing sources of water, as well as extracting and transferring water from valleys to highlands. ${ }^{5}$ The Fuqaha' applied this science in the built environment based on the most important principles of Islamic Fiqh, the realization of benefit and prevention of harm. ${ }^{6}$

The famous Fuqaha' who were interested in the built environment originated from Madhhab Al-Maliki. They authored various worthy books in the easement and provisions of architecture. These include, but are not limited to:

1. Al-Qada' Fi Al-Bunian (Judiciary in Architecture) by Abdullah bin Abdul-Hakam (271 A.H.). This is one of the oldest books in terms of provisions of architecture. ${ }^{7}$

2. Al-Qada' Bil Murfaq Fi Al-Mabani Wa Nafi Al-Darar (The Judiciary in the Easement and Prevention of Harm) by Imam Issa Bin Musa Al-Tatili (386 A.H.).

3. Al-Iklan Fi Ahkam Al-Bunian (The Declaration of the Provisions of Buildings) by Muhammad bin Ibrahim famed as Ibn Al-Ramy Al-Tunisi (739 A.H.).

\footnotetext{
* Ziad M. M. Shehada, Researcher, Faculty of Built Environment, University of Malaya, Kuala Lumpur. Email: archzms@gmail.com.

${ }^{1}$ Barbara A. Roberson (2013), Shaping the Current Islamic Reformation, London: Frank Cass, p. 23.

2 Ibrahim Kutluay (2011), "The meaning and scope of Sunnah according to Imam Mālik and the practice of the people of Medina," Energy Education Science and Technology Part B: Social and Educational Studies, Vol. 3, No. 3, p. 361.

${ }^{3}$ Kutluay (2011), "The meaning and scope of Sunnah according to Imam Mālik," p. 364.

${ }^{4}$ The Arab League Educational, Cultural and Scientific Organization (2004), Mawsua'at A'alam Al-Ulama' Wa Al-Udabaa' Al-Arab Wa AlMuslimin, Lebanon: Dar Al-Jil, p. 115.

${ }^{5}$ Siddiq B. Al-Qanouji (1978), Abjad Al-Ulum, Syria: Ministry of Culture \& Dar Al-Kutub Al-Ilmiyah, p. 384.

${ }^{6}$ Juan M. Quesada (2005), El mundo jurídico en Al-Andalus, Spain: Delta Publicaciones Universitarias, p. 17.

Ibn Farhoun I. Ya'amuri (1996), Al-Debaj Al-Muthahhab Fi Tarajim A'ayan Al-Mathhab, Lebanon: Dar Al-Kotob Al-Ilmiyyah, p. 134.
} 
The Islamic cities were subject (in whole or part) to Fiqh provisions, whether stipulated or Ijtihad (independent reasoning). These provisions are continuously renewed according to societal evolution. ${ }^{8}$

\section{Methodology}

The researcher has adopted a descriptive-analytic methodology to analyze and understand the relationship between Islamic Fiqh and built environment. The descriptive-analytic methodology is one of the important scientific research approaches, whereby the researcher can identify the phenomenon accurately. In addition, such methodology enables the researcher to solve the problem and improve the practices through observation, analysis, and description. ${ }^{9}$

The researcher collected secondary data from juristic references, books, research papers, and Internet sites. Meanwhile, the primary data were collected by analyzing the texts and Ulama' opinions. The research analysis includes five categories that contributed toward the formation of the city and the built environment from different perspectives: consideration of privacy and sanctity, preservation of the environment in the city, consideration of health conditions in the city, safety conditions of construction in the Islamic Fiqh, and the Islamic Fiqh and road maintenance.

The researcher studied and analyzed the jurisprudential and heritage sources of Fiqh Al-Maliki that are related to buildings and architecture based on the four rules in the Fundamentals of Maliki jurisprudence associated with building provisions, which are: realization of benefit and prevention of harm, consideration of public interest over self-seeking interest, committing the lesser of two harms, and arbitration of the Urf (prevailing custom). The analysis of the influence of Fiqh Al-Maliki on the built environment is elicited depending on the fundamental rules in addition to events, paradigms, stories, and clues that occurred in the Islamic era. The understanding of these rules will pave the way for scientists and architects in a broader and more comprehensive understanding of how the city was formed in the Islamic period.

\section{The Fiqh Rules Regulated Ancient Urban Development}

The ancient Islamic cities were built based on jurisprudential systems and regulations utilized to solve dilemmas and difficulties. ${ }^{10}$ These provisions relied on general Fiqh rules supported by Fuqaha' and they are summarized as follows.

\section{Realization of Benefit and Prevention of Harm}

The Fuqaha' derived the provisions related to buildings and architecture from the rule on prevention of harm. ${ }^{11}$ They relied on concrete Shari'ah evidences that prevent harm, like the Hadith of Prophet Muhammad (Peace be upon him): "There should be neither harming nor reciprocating harm." 12 Most of the easement issues depended on this Hadith. The matter of easements in Madhhab Al-Maliki combined with prevention of harm very strongly. This was clear in the chapters' titles, as stated by Ibn Juzayy Al-Ghirnati (741 A.H.) in Section 15 where he talked especially about "Facilities and Prevention of Harm." ${ }^{\text {"13 }}$ They adopted this rule in all easement issues; for example, prevention of the tanner who harms his neighbors by smelly tanning (Figure 1), prevention of public ovens and Hammams (baths) (Figure 2), trashing floors near gardens, orchards, as well as anything that might hurt the built environment. ${ }^{14}$

\section{Consideration of Public Interest Over Self-Seeking Interest}

Interests can be divided into self-seeking interests (the beneficiaries are individuals) and public interests that benefit everybody. Sometimes, problems and conflicts occurred between these two interests, especially with regard to the built environment. The Fuqaha' resolved such conflicts in favor of public

\footnotetext{
${ }^{8}$ Mashood A. Baderin (2017), Islamic Legal Theory (Usūl Al-Fiqh), Vol. 1, London: Taylor \& Francis, p. 63.

${ }^{9}$ Eunsook Koh and Willis Owen (2000), "Descriptive Research and Qualitative Research," in Introduction to Nutrition and Health Research, Boston: Springer, p. 219

${ }^{10}$ Hassan Riaz (2018), "Religion, Modernization And The Islamic Ummah," Journal of Al-Tamaddun, Vol. 13, No. 1, p. 59.

${ }^{11}$ Besim S. Hakim (2001), "Reviving the rule system. An approach for revitalizing traditional towns in Mahgrib," Cities, Vol. 18, No. 2, p. 89

${ }^{12}$ Malek B. Anas (2018), Muwatta Imam Malik, Aleppo: Dar Ihya’a At-Turath Al-Arabi, Kitab Al-Aqdiyah, Bab Al-Qada'a fi Al-Merfaq, Hadith No. 1234. p. 342.

${ }^{13}$ Ibn Juzayy M. Al-Gharnati (2016), Al-Qawanin Al-Fiqhiyyah, Beirut: Dar Al-Kutub Al-Ilmiyyah, p. 223.

${ }^{14}$ Alan Verskin (2013), “The Evolution of the Maliki Jurists' Attitudes to the Mudejar Leadership,” Der Islam, Vol. 90 , No. 1, pp. 50.
} 
interest given the strength of evidences and public benefits. ${ }^{15}$ For example, they prevented the expansion of personal easements at the expense of public alleyways and yards, deducing on what was reported, "A blacksmith built a forge in the Muslim market, Khalifa Umar bin Al-Khattab (May Allah be pleased with him) was walking and saw him, he said you disparaged the market, then ordered to tear down the smithy."16

Based on the quote mentioned above, Imam Ash'hab Al-Maliki (204 A.H.) believed that the Sultan (king) has the authority to order the demolition of any illegal aggression on public alleyways (Figure 3). "No one can take any meter from the Muslims' road, whether it is large or not, harmful or not, otherwise, it must be immediately demolished." 17 Another evidence of the priority placed on public interest is when Khalifa Umar bin Al-Khattab gave building owners the right to use the courtyards among their buildings. He allowed them to use the courtyards for setting, discussing, selling fast food, and prevented possession or fencing. ${ }^{18}$

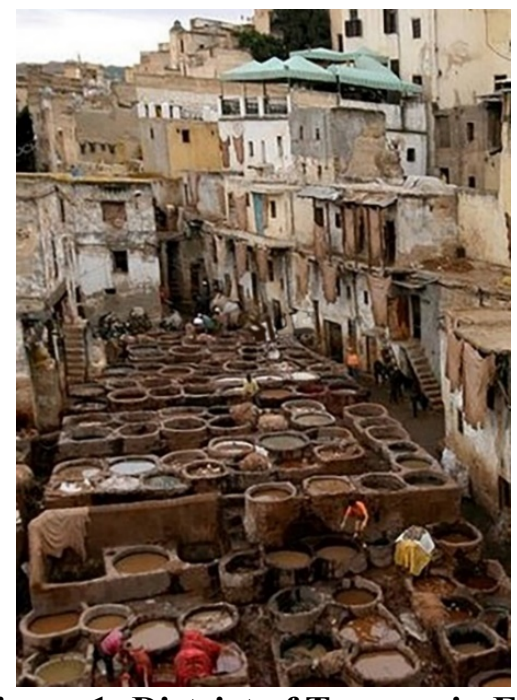

Figure 1: District of Tanners in Fes, Morocco $^{19}$

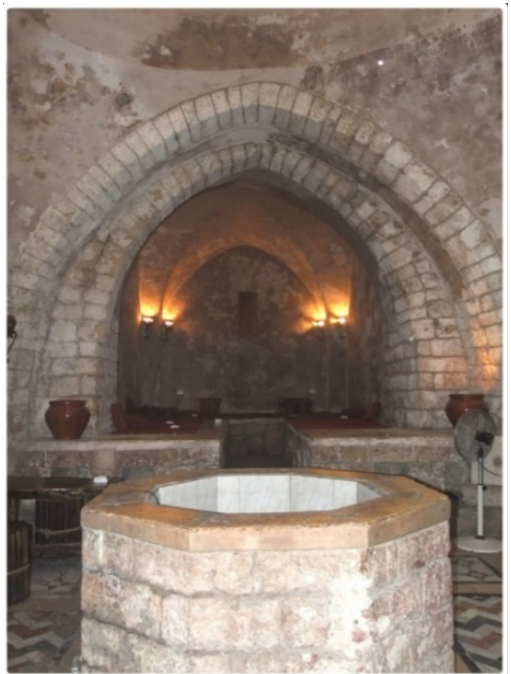

Figure 2: Hammam As-Samara in Palestine $^{20}$

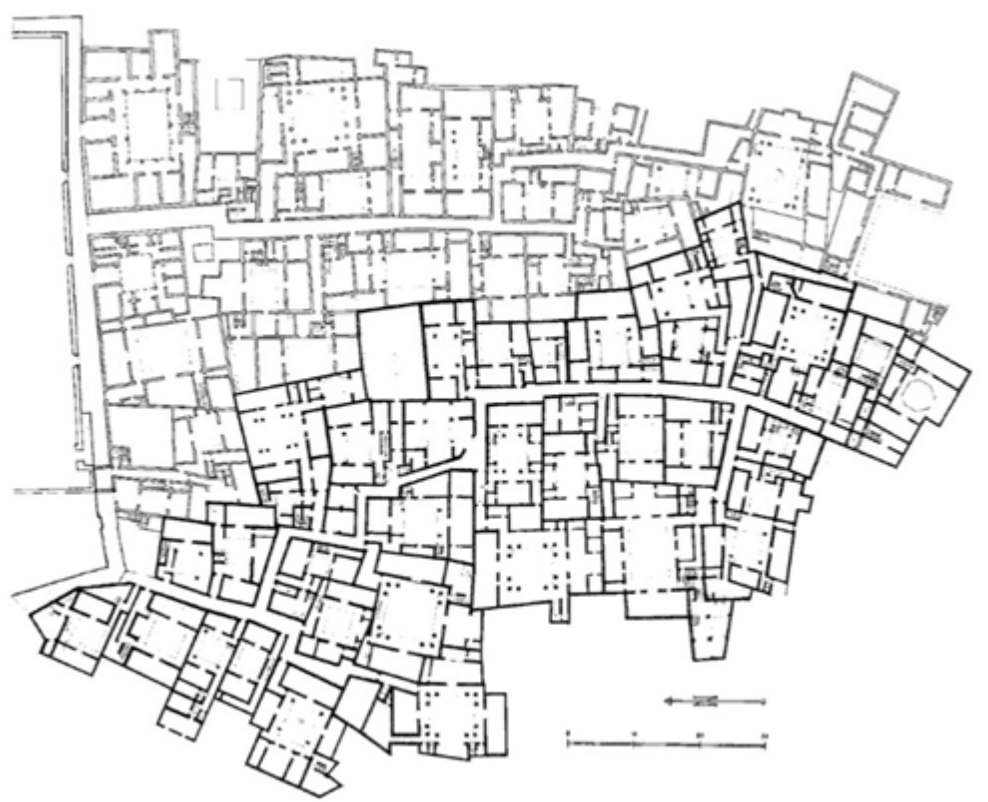

Figure 3: Site Plan of Fez Containing Courtyards and Alleyways ${ }^{21}$

\footnotetext{
${ }^{15}$ Ali M. Al-Jurjani (2011), At-Tareefat, Egypt: Sar Ar-Rayyan Le At-Turath, p. 193.

${ }^{16}$ Mohammad M. Al-Hattab (2010), Mawaheb Al-Jalil Fi Sharh Mukhtasar Khalil, Jordan: Dar A1 Radwan, p. 153.

${ }^{17}$ Issa M. At-Tutili (1999), Al-Qada’ Bil Murfaq Fi Al-Mabani Wa Nafi Al-Darar, Rabat: Islamic Educational, Scientific and Cultural Organization (ISESCO), p. 121.

${ }^{18}$ Ibn Ar-Rami, Ahmad A (1999), Al-Iklan Fi Ahkam Al-Bunian, Ishbiliyah: Media and research center, p. 79.

${ }^{19}$ Lucas Peters (2017), Moon Morocco, New York: Avalon Publishing, p. 146.

${ }^{20}$ The researcher.

${ }^{21}$ Stefano Bianca (2000), Urban Form in the Arab World: Past and Present, United Kingdom: Thames \& Hudson, p. 62.
} 


\section{Committing the Lesser of Two Harms}

The consensus of Fuqaha's opinions was based on the principle of committing the lesser of two harms. ${ }^{22}$ It means that the lesser harm becomes permissible to avoid the greater evil. This rule is applicable to all aspects of life, particularly in the fields of architecture and construction. For instance, the Fuqaha judged that a person has to permit access to his neighbor's workers and builders through his house to repair the wall between them. As this sets off two harms (entering the neighbor's house and the necessity of repairing the wall), entering the neighbor's house is the lesser of two harms. ${ }^{23}$

\section{Arbitration of the Urf (Prevailing Custom)}

Urf is a set of agreed, stipulated or generally accepted standards. ${ }^{24}$ It also can be defined as social norms or criteria, and often takes the form of a custom. ${ }^{25}$ It is considered to be an important legislation evidence to implement the provisions in many areas such as personal status, treatment sections, and others. The Fuqaha' depended heavily on this rule predominantly in dispute resolution between the adversaries in terms of the easement rights. As stated in several Fiqh books, "If a wall is quarreled between two houses, it is judged to whom the $\operatorname{Urf}$ (custom) supports."26

Based on these four rules, the research contributed toward addressing this issue by revealing certain details of the urban dimensions in Fiqh Al-Maliki through five aspects.

\section{First Aspect: Consideration of Privacy and Sanctity}

The Muslims in the ancient cities absorbed the Fiqh principles and embodied them in the buildings' design, especially elements related to the preservation of privacy and consideration for personal life. In terms of privacy, the Islamic Fiqh, in line with the provisions of Shari'ah, focused on respecting residential houses for fear of revealing the private lives and secrets of the people. ${ }^{27}$ The design of the housing buildings was in a special pattern to prevent any violation of sanctity and private parts. The Figh was very strict to prevent any breach of these principles, as mentioned in Al-Mudawanah's book, "It is prohibited for a man to open a window or any hole in the wall that reveals his neighbor's privacy." ${ }^{28}$ Khalifah Omar bin Al-Khattab (May Allah be pleased with him) also wrote, "The window or hole in the wall should be high to an extent that the man cannot see his neighbor even if he stands on a bed. ${ }^{29}$ All these restrictions were aimed to prevent any harm or damage. Such bans explain why the windows in the old cities were small and high, and opened toward the courtyards and not outside.

In terms of sanctity, as a dedicated place for worshiping Allah and performing prayers, the mosque played an important role in the development of the ancient cities. The vastness of the courtyards and the centrality of the ancient mosques are a clear evidence of respect for privacy (Figure 4). Names such as The Great Mosque and The Big Mosque further indicate the importance of the mosques. ${ }^{30}$ The mosques also occupied a respectable position in the metropolitan areas represented by religious and spiritual symbolism; for example, Al-Qarawein Mosque and Al-Koutoubia Mosque. ${ }^{31}$ The Fuqaha' prohibited the construction of a house over a mosque to maintain the religious character and spiritual status of the latter. Imam Malik was asked, "What if a mosque was built by a man and he built a house over it?" He said, "I don't like that as it will be used for sexual intercourse, cooking, eating and so on." 32 The upstairs of the mosque is also considered a harem and should not be violated. Imam Al-Qarafi issued a Fatwa stating that: "The house is permissible to be downstairs and the mosque is upstairs, but the opposite is forbidden." 33 They leant on the evidence of Omar bin Abdul Aziz (May Allah be pleased

\footnotetext{
${ }^{22}$ Harald Motzki (2002), The Origins of Islamic Jurisprudence: Meccan Fiqh Before the Classical Schools, Netherlands: Brill Publishers, pp. 76-77.

${ }^{23}$ Mohammad A. Al-Dosouqi (2016), Hashiat Al Dusooki Al Al Shareh Al Kabir V4, Lebanon: Dar El Fikr for Printing publishing and distribution (S.A.L.), p. 367.

${ }^{24}$ Abu Al-Fath A. Al-Hanbali (2013), Al-Matla'a Ala Abwab Al-Muqne'a, Saudi Arabia: Al-Maktab Al-Islami, p. 264.

${ }^{25}$ Muhammed A. Ar-Razzi (1999), Mukhtar As-Sihah, Vol. 5, Saida: Al-Maktabah Al-Asriyah An-Namothajiyyah, p. 179.

${ }^{26}$ Abi Abdul Rahman O. Al-Mazari (2015), Sharh At-Talqen Fi Al-Fiqh Al-Maliki Le Al-Qadi Al-Baghdadi, Lebanon: Dar Al Kotob Al Ilmiyah, p. 193.

${ }^{27}$ Besim S. Hakim (2001), "Reviving the rule system," pp. 109-110.

${ }^{28}$ Ibn Saed A. Sahnun (2005), Al-Mudawwana Al-Kubra lil Imam Malik Ibn Anas, United Arab Emarates: Dar Sader, p. 529.

${ }^{29}$ Shebuddin A. Al-Qurafi (1994), Ath-Thakhirah, Beirut: Dar Al-Gharb Al-Islami, p. 175.

${ }^{30}$ Spahic Omer (2009), Islam, Architecture and Urban Planning, Malaysia: Arah Pendidikan Sdn Bhd, p. 97.

${ }^{31}$ Muhammad I. Salih and Abdul Hafiz F. Qoqani (1999), The urban design of mosques, Kuwait: The Ministry of Higher Education in Collaboration with the Ministry of Islamic Affairs, pp. 45-46.

${ }^{32}$ Abu A. Al-Abdary (1994), At-Taj Wa Al-Iklil Fi Sharh Mukhtasar Ash-Shiekh Khalil, Beirut: Dar Al-Kutub Al-Ilmiyah, p. 17.

${ }^{33}$ Mohammad W. Abbah (2011), Madkhal Ila Usul Al-Fiqh Al-Maliki, Morocco: Dar Al-Aman, p. 38.
} 
with him) who slept at the top of a mosque and did not approach any woman. ${ }^{34}$ In contrast, Figh AlMaliki permitted the construction of high-level mosques. Imam Malik said, "It is permissible to have a house under the mosque and the house could be inherited but the mosque could not as it is Waqf for the public." 35

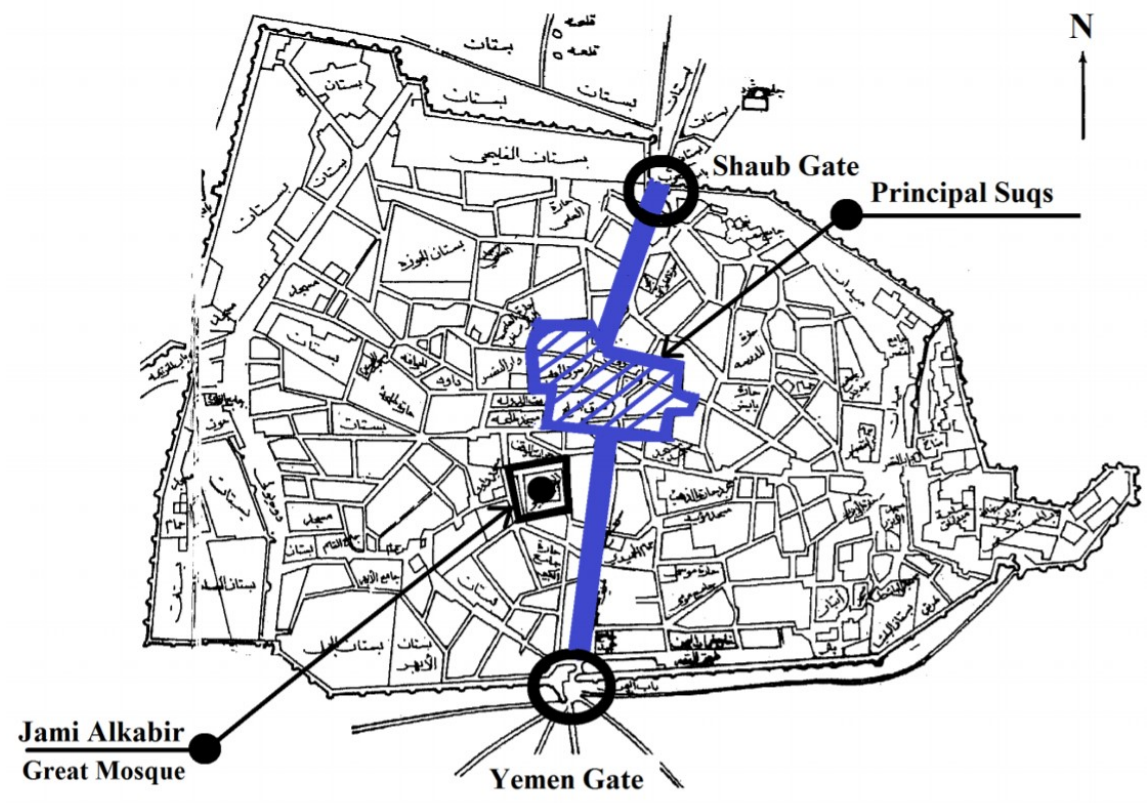

Figure 4: Site Plan of Sana'a Showing the Centrality of the Mosque $e^{36}$

The Figh in the old urban development also decided that each structure must have a harem that should be respected. The harem in the construction Figh is the spatial boundary surrounding the building, alleyway, or city and left as a reserve for expansion when needed. ${ }^{37}$ Accordingly, the Fuqaha' talked about many kinds of harems. One of the Fuqaha' of Al-Maliki said, "The harem of the well is what surrounds it, and differs depending on the well's size (big or small) and the strength of land (hard or soft); the harem of the house is the entrance, exit, and control positions; the harem of the acre is the edges, entrance, and exit; the harem of the village is the place of firewood and pasture." 38 The harem has provisions mostly on the control of exploitation in an alleyway that does not harm the public interest, where the Fuqaha' considered the harem as a public benefit, even if it was in private ownership, such as courtyards. In this context, they forbade the exploitation of the city's harem unless the state gave permission after considering public interest, even if the harem was not in the ownership of anyone. As mentioned in the book of Figh laws, "Whoever revived a dead land (Mawat), he will own it. ${ }^{39}$ The revival shall be through construction, planting, agriculture, plowing, water treatment, etc. If the Mawat land is close to the urban area, it needs permission from the Sultan; whereas if it is far, it does not need permission." ${ }^{40}$

\section{Second Aspect: Preservation of the Environment in the City}

The Fuqaha' attached importance to the environment based on the Quranic verses and Sunnah texts that urged Muslims to preserve the architecture and environment. They also seriously considered Ijtihad in deriving provisions that framed the field urbanism in the light of sound environmental conditions. Based on the principle of prevention of harm, the Fuqaha' addressed the environmental field in terms of its impact on people's necessities in life. ${ }^{41}$ They affirmed that the environment must be preserved,

\footnotetext{
${ }^{34}$ As-Sanhouri, Abi An-Naja S (2019), Tayseer Al-Malik Al-Jalil Le Jama’ Al-Shorouh Wa Hawashi Khalil Fi Al-Fiqh Al-Maliki, Lebanon: Dar Al Kotob Al Ilmiyah, p. 221.

${ }^{35}$ Adel A. Al-Dosary (2014), Principles For The Rejuvenation Of An Islamic City In The Modern Context: The Case Of Medina Of Tunis, Italy: EDUCatt Università Cattolica, p. 83.

${ }^{36}$ Hossein Soltanzadeh and Mohammadreza Sadeghi Moghaddam (2015), "Sana'a, Structure, Historical Form, Architecture and Culture," Civil Engineering and Architecture, Vol. 3, No. 3, pp. 56-67.

${ }^{37}$ Al-Gharnati (2016), Al-Qawanin Al-Fiqhiyyah, p. 222.

${ }^{38}$ As-Sanhouri (2019), Tayseer Al-Malik Al-Jalil Le Jama' Al-Shorouh, p. 197.

${ }^{39}$ Hailani M. Tahir (2019), The Conceptual Idea of the Mua'Malat Fiqh Forensic in the Islamic Financial System, Singapore: Partridge Publishing Singapore, p. 88.

${ }^{40}$ Sahnun (2005), Al-Mudawwana Al-Kubra lil Imam Malik Ibn Anas, p. 243.

${ }^{41}$ Verskin (2013), “The Evolution of the Maliki Jurists' Attitudes to the Mudejar Leadership,” pp. 49.
} 
not harmed, and considered the environment as a protective bulwark for the continuation of human life. Therefore, they transferred the industrial facilities to the outside of the city, ${ }^{42}$ and preserved the harem, house courtyards, gardens, orchards, and water, in addition to the adjustment of the provisions and sanctions that ensured environmental safety in Islamic cities.

Just as the modern cities have developed industrial districts relatively far from the population to avoid harming people, the Islamic cities had taken this step even earlier. The Fuqaha' in their Fatwas and judiciary prevented the erecting of Hammams, bakeries, mills, tanneries, and blacksmith shops amid residential houses. Imam Sahnoun Al-Maliki (240 A.H.) narrated, "Anyone who establishes bakehouses or forge and harms his neighbor; it must be forbidden." ${ }^{43}$ Imam ibn Al-Qasim (191 A.H.), a well-known Maliki Fuqaha', was also asked about the issue of "A man has a land amid other houses, he wants to build a Hammam or bakery in that area, and the neighbors objected. He said if this shop caused harm for the neighbors like noise, smoking and so on, the neighbors have the right to prevent him.."

The Fuqaha' depended on the rule of prevention of harm and identified the expected damage from industries across several points.

- Smoke and gases: The gases that emit from industries affect health and environmental conditions. As the Fuqaha' had previously considered this danger, they prevented the factories from being built in residential areas to avoid the emission of liquid and gaseous waste such as the smoke released by the furnace to dissolve metals and the Hammam. ${ }^{45}$

- Bad odors: Since ancient times, the Muslim Fuqaha' had considered the impact on the environment, including smell. A Canadian physician philosopher wrote a book titled "Healing Medicines from Harmful Smells." The Fuqaha' of Madhhab Al-Maliki such as Ibn Almajsheon (212 A.D.), Matarif (220 A.H.), and Asbagh (225 A.H.) agreed that if the tanner annoys his neighbors with tanning and stinking odors, it should be stopped. ${ }^{46}$

- Annoying sounds: It is stated in Fiqh Al-Maliki that "Prevention of erecting industries that cause annoying sounds amid the inhabitants, such as those who use quern (hand mill) in the houses and bother their neighburs." ${ }^{47}$

- Wall cracks: Imam Ibn al-Qasim asked to stop using the querns that were adhered to the residential buildings as they may damage the walls. ${ }^{48}$

According to these various harms, the Fuqaha' prevented the tenants from using shops for such industries. As stated in the book of Al-Mudawanah Al-Kubra: "A man rents a shop and does not identify the work to the owner, then uses the shop as a smithy, flouring, milling or anything else." ${ }^{" 49} \mathrm{Ibn}$ alQasim said, "If the work causes harm to the building or damages the shop, it must be immediately stopped." ${ }^{, 5}$ Based on the expected damages from industries, they were obliged to remove the harmful industries from the residential areas and decided to allocate particular spaces depending on the vocation. Therefore, neighborhoods in the ancient cities are known by names derived from their industry; for instance, the district of tanners, spice dealers, dyers, quicklime dealers, blacksmiths, and carpenters. ${ }^{51}$ The Fuqaha' excluded cooking ovens; these could be erected amid the people according to the interest and benefit. Some Fuqaha' even considered that evacuating the neighborhood where the ovens existed were an ordeal for the tenants, and thus the owners should decrease the price as much as the loss. ${ }^{52}$

Besides, it was common for the people to plant trees and flowers in the courtyards in order to form green fields and enhance the beauty of their houses. Consequently, the Fuqaha' prevented any attacks on these plants. Ibn Rushd was asked about a situation in which a man planted flowers in the courtyard of another man and took advantage of it, before the owner asked him to remove the flowers and pay for the damage. He replied, "Don't remove the flowers as the man planted the roses for only some time

\footnotetext{
42 Yahya Waziri (1999), Mawsu'ah 'anasir al-'imarah al-Islamiyah, Egypt: Maktabah Madbuli, p. 48.

${ }^{43}$ At-Tutili (1999), Al-Qada’ Bil Murfaq Fi Al-Mabani Wa Nafi Al-Darar, pp. 120-121.

${ }^{44}$ Sahnun (2005), Al-Mudawwana Al-Kubra lil Imam Malik Ibn Anas, p. 529.

${ }^{45}$ Al-Gharnati (2016), Al-Qawanin Al-Fiqhiyyah, p. 224.

${ }^{46}$ Al-Mazari (2015), Sharh At-Talqen Fi Al-Fiqh Al-Maliki, p. 5.

${ }^{47}$ Al-Qurafi (1994), Ath-Thakhirah, p. 175.

${ }^{48}$ Al-Gharnati (2016), Al-Qawanin Al-Fiqhiyyah, p. 225.

${ }^{49}$ Sahnun (2005), Al-Mudawwana Al-Kubra lil Imam Malik Ibn Anas, p. 523.

${ }^{50}$ Ahmad M. At-Tulaitili (2000), Al-Muqnea' Fi Ilm Al-Shorout, Lebanon: Dar Al-Kotob Al-Ilmiyyah, p. 234.

${ }^{51}$ Yahaya Wazire (2004), Islamic Architecture and Environment, Kuwait: National Council for Culture, Arts and Letters, p. 66.

${ }^{52}$ Al-Hattab (2010), Mawaheb Al-Jalil Fi Sharh Mukhtasar Khalil, p. 174.
} 
when there was no ownership, the priority is also on the interest and benefit." ${ }^{, 53}$ The Tunisian Imam, Ibn Arafah al-Warghmi (748 A.H.) opined, "Whoever complained about a tree in his neighbor's house, let him not to cut or touch it except the branches that entered his house." ${ }^{54}$ Moreover, the Fuqaha' of Maliki prevented littering the floors created around the gardens because it harms the cereals and seeds (same effects as Hammams and bakehouse). Ibn Habib Al-Maliki said in terms of the mixed trees or forested land adjacent to the villages and amid the cities, "The Sultan should not order to cut any because they are not the kind of lands used by the public, but one of their rights (exactly like the courtyard for the house). ${ }^{, 55}$ The cutting of trees will affect the facilities nearby that depend totally or partially on the green area. The Fuqaha' also kept the banks of the rivers clean and free of any buildings as they did not allow anyone to build on the shore of the river for housing or other facilities except the needed arcades and arches. ${ }^{56}$

\section{Third Aspect: Consideration of Health Conditions in the City}

One of the overall purposes of the Islamic law is to preserve the human soul, mind, and spirit in all aspects of life. As the health sector was the greatest, the Fuqaha' codified many things in the city. For instance, wastewater is harmful and as it is a source of dirt and impurity, it could cause many health problems. Therefore, Fiqh Al-Maliki regulated the city's water drainage through procedural measures that prevented water drainage from the houses to the alleyways and streets. Imam Sahnoun proved that when he was asked, "Is it permissible for a man to open a ground hole in the Muslims' way to take out his water?" He replied that he could do so. ${ }^{57}$ Fiqh Al-Maliki also prevented water drainage that inflicted damage to the neighbors and their walls, where this harm is agreed upon. These evidences indicate that the inhabitants of the old cities followed another method for draining the wastewater, which are underground sewage pipes and channels to avoid the dirt, odors, and harm. ${ }^{58}$ Moreover, Fiqh Al-Maliki differentiated wastewater from rainwater. The first should not be taken out to the public ways, whereas the second could be run outside the house even if was poured in the alleyway because it is inevitable damage. However, they accentuated that gutters must be made to drain the rainwater. ${ }^{59}$

The toilets were also a key concern to the Fuqaha' that strived to preserve human health. When asked if the damaged toilet was owned by the upstairs or the downstairs resident, Imam Ibn al-Qasim said that the downstairs owner should build the downstairs structures to reach the ceiling, and the upstairs owner should build the wood ceiling. ${ }^{60}$ In terms of cleaning, the Fuqaha' of Madhhab Al-Maliki affirmed that toilet cleaning is mandatory. In a case of a dispute among the partners of a privy on who bears the cleaning expenses, the Fuqaha' replied that the expenses are divided between the partners as much as the people in each house. ${ }^{61}$ Furthermore, when the owner rented out his house, he was made to clean the dirt and toilet pit unless the owner bargained with the tenant to do so. ${ }^{62}$ Therefore, it can be concluded that the toilet wells in the old cities were shared among a group of people, and they used the same drainage system for the valley water.

Additionally, due to the necessity of light and sun for healthy housing, the Fuqaha' permitted niches and windows to let light and air go through the houses provided that the neighbors were not harmed. One imam of Madhhab Al-Maliki was asked about a situation in which a man opens a window in his wall and his neighbor dislikes that even though the window is high to an extent that can only be reached by a ladder. He replied, "If there is no harm to his neighbor, I see nothing wrong because it is an interest." ${ }^{\prime 3}$ It is reported in the Al-Thakirah book of Imam Qurafi, "Some of our companions said that it is forbidden to close the window holes in the buildings because they are necessary to avoid darkness and circulate the internal air." ${ }^{64}$

\footnotetext{
${ }^{53}$ Ibid p. 184.

${ }^{54}$ Al-Abdary (1994), At-Taj Wa Al-Iklil Fi Sharh Mukhtasar Ash-Shiekh Khalil, p. 174.

${ }^{55}$ Qutub Raysouni (2008), Nawazel Ahmad Bin Saeed Bin Bashtaqeer Al-Lawraqi Al-Maliki, Beirut: Dar Ibn Hazm, p. 150.

${ }^{56}$ Al-Hattab (2010), Mawaheb Al-Jalil Fi Sharh Mukhtasar Khalil, p. 12.

${ }^{57}$ Al-Mazari (2015), Sharh At-Talqen Fi Al-Fiqh Al-Maliki, p. 98.

${ }^{58}$ Yahaya Wazire (2004), Islamic Architecture and Environment, Kuwait: National Council for Culture, Arts and Letters, p. 79.

${ }^{59}$ Al-Dosary (2014), Principles For The Rejuvenation Of An Islamic City, p. 83.

${ }^{60}$ At-Tutili (1999), Al-Qada' Bil Murfaq Fi Al-Mabani Wa Nafi Al-Darar, p. 100.

${ }^{61}$ Al-Gharnati (2016), Al-Qawanin Al-Fiqhiyyah, p. 229.

62 At-Tulaitili (2000), Al-Muqnea' Fi Ilm Al-Shorout, p. 101.

${ }^{63}$ Ihsan Zaqour (2005), Al-Qawaed Al-Fiqhiyyah Al-Mustanbatah Min Al-Mudawanah Al-Kubra Lel Imam Malik, Lebanon: Dar Ibn Hazm, p. 181 .

${ }^{64}$ Al-Qurafi (1994), Ath-Thakhirah, p. 197.
} 


\section{Fourth Aspect: Safety Conditions of Construction in the Islamic Fiqh}

The consideration of building safety conditions to avoid expected damages was obvious in the Islamic Figh codification of the built environment issues. The Fuqaha' were keen to control the procedures in accordance with the rules of perfect architecture to prevent disasters and pandemics. As a result, they emphasized various requirements to achieve maximum safety.

Multi-storey buildings were common in ancient civilizations. As wood was often used in ceilings, they were vulnerable to fragility and erosion. Therefore, the Fuqaha' stipulated that the walls and ceilings must be strong enough to bear the floors. Imam Ibn al-Qasim was asked, "If the upstairs owner wants to build one more floor, what about if the basement owner wants to prevent him?" He said, "If the new floor is lightweight, which does not harm the whole building, it is up to him; but if there is any suspicion of damage, he must be forced to stop." ${ }^{65}$ For fear of the floor's load on the wooden ceiling, Imam Ashhab (Madhhab Al-Maliki) expressed his opinion by stating, "If a piece of wood in the ceiling is broken, it should be replaced with an equivalent piece not heavier that may cause hurt."

The Fuqaha ' built their opinions depending on the principle of prevention of harm as much as possible, but they stipulated no leniency toward the risks caused by the dilapidation of buildings and walls. Imam Ibn al-Qasim was asked, "A wall between two neighbors tilted so severely and became ramshackle. Do you think the Sultan will order the owner to tear down the wall if the neighbor complained?" He said, "Yes, the wall must be demolished." $" 67$

In the context of considering construction rules, the Fuqaha' did not allow any imbalanced architecture. Imam Ibn al-Qasim was also asked, "A man built a multi-storey building and expanded the upstairs level horizontally over his neighbor's land, which prevents the neighbor to expand vertically. Do you think that he must demolish the protruding parts over his neighbor's land?" He answered, "Yes, he does not have the right to infringe upon the space above the land." ${ }^{\circ 6}$ Fiqh Al-Maliki did not take into account the expenses spent on the wall if it is in breach of the architectural regulations. It was said to Ibn AlQasim that demolition costs great expense and wastes much money, but he insisted that it must be demolished regardless of cost. ${ }^{69}$ This kind of Fiqh is necessary for the following two reasons:

- First, it prevents infringement on the rights of others (land, air, or any construction field).

- Secondly, tilting walls often lead to collapse. Hence, to consider the safety requirements, the tilting walls should be adjusted or demolished.

Furthermore, one of the requirements of the ancient architectural art was the erection of shelves and balconies overlooking the alleyways, as long as these elements were built in a balanced way and the Fiqh adjusted the conditions. Imam Abdul Salam Sahnoun was asked about the possibility of erecting shelves and balconies overlooking the alleyway. He said, "I do not see any problem with that unless they harm someone." ${ }^{, 70}$ One of the conditions imposed is the height of the balcony, so as not to cause harm to the pedestrians, horse riders or cattle when they pass under or near it. Otherwise, the Fuqaha' of Maliki stated that it must be demolished to prevent harm from happening to other people. ${ }^{71}$

\section{Fifth Aspect: The Islamic Fiqh and Road Maintenance}

The Fuqaha' made connections between the breadth of a road and type of use. They wrote a great rule in the disparity of the ancient cities' ways, as stated by some Fuqaha', "The people must design the alleyways as wide as the broadest and greatest thing can pass. Therefore, the alleyway should be fitting

\footnotetext{
${ }^{65}$ At-Tutili (1999), Al-Qada’Bil Murfaq Fi Al-Mabani Wa Nafi Al-Darar, p. 97.

${ }^{66}$ Abdul Hafiz F. Qoqani and Muhammad I. Salih (1999), The Islamic jurisprudence about mosque architecture, kingdom of saudi arabia: King Saud University, p. 45.

${ }^{67}$ Basher A. Jazaeri (2008), Usul wa Furu'fi Al-Mashreq Al-Arabi Qadem wa Hadith: Masader Al-Fiqh Al-Maliki, Msaytbeh: Dar Ibn Hazm, p. 141 .

${ }^{68}$ At-Tutili (1999), Al-Qada’ Bil Murfaq Fi Al-Mabani Wa Nafi Al-Darar, pp. 142-143.

${ }^{69}$ Adel A. Shakour and Salah Iwaidah (2010), Hashiyat Ash-Shaikh Ibrahim Al-Baijouri Ala Sharh Al-Allamah Aby Al-Qasem, Cairo: Shorouk International Bookshop, p. 111.

${ }^{70}$ As-Sanhouri (2019), Tayseer Al-Malik Al-Jalil Le Jama'Al-Shorouh, p. 99.

${ }^{71}$ Sayyid M. Al-Hasani (2005), Fiqh Keluarga: Seni Berkeluarga Islami, Indonesia: Bina Media, p. 139.
} 
for the burden camels, wheels, horse-drawn carriages and so on.",72 Based on this rule, they distinguished between three types of alleyways and determined their breadth.

- The walkers' way (pedestrians): The width had to be seven cubits (Figure 5). If less, it should be increased by taking from the people's land to be seven cubits. ${ }^{73}$ This was based on the Hadith of Prophet Muhammad (PBUH): "If the people differ about the way, seven cubits is the minimum."

- Cattle and cows' way: Twenty cubits wide ${ }^{75}$ (Figure 6).

- The way of the Makhda'a (A small house inside a big house) was a minimum of four cubits ${ }^{76}$ (Figure 7).

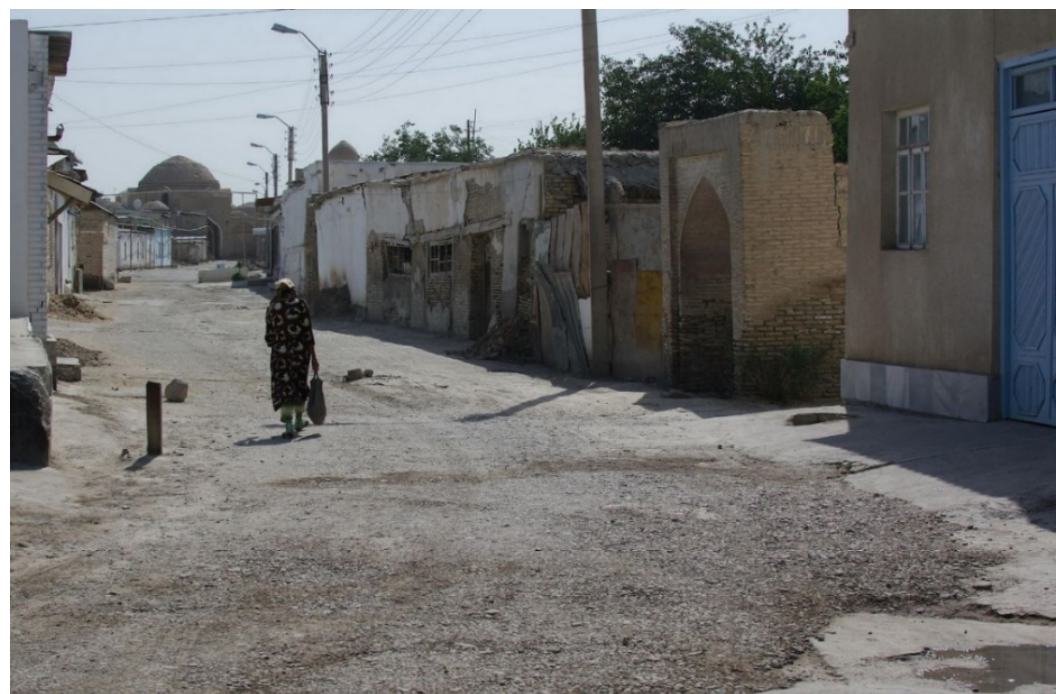

Figure 5: Wide Alleyway Almost 20 Cubits in Bukhara ${ }^{77}$

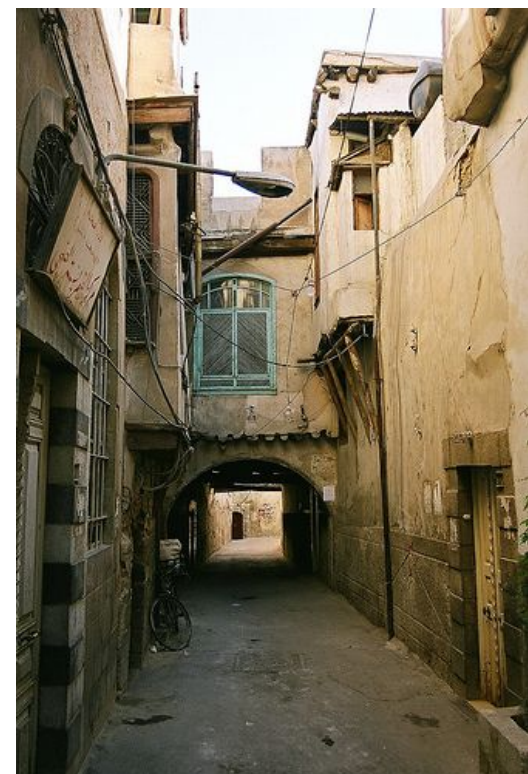

Figure 6: The Walkers' Way in Old Damascus $^{78}$

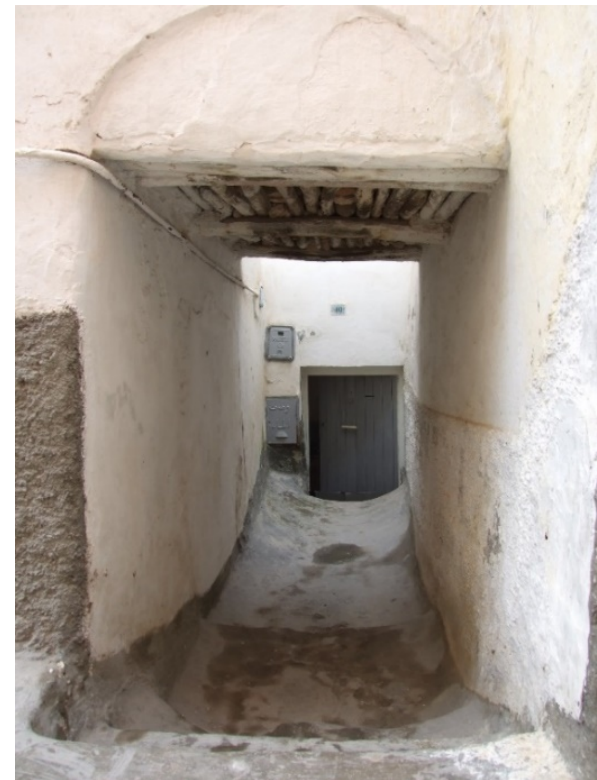

Figure 7: Al-Makhda'a Way in Old Damascus $^{79}$

The Fuqaha' unanimously agreed on preventing the narrowing of the public ways by taking possession of the alleyways according to the Hadith of Prophet Muhammad (PBUH), "Whoever seizes an inch of

\footnotetext{
72 Jonathan Brockopp (2000), Early Maliki Law: Ibn 'Abd Al-Hakam and His Major Compendium of Jurisprudence, Netherlands: Brill Publishers, p. 83.

${ }^{73}$ Zaqour (2005), Al-Oawaed Al-Fiqhiyyah, p. 69

${ }^{74}$ Mohammad I. Al-Bukhari (2013), Sahih Al-Bukhari, Aw, Al-jami' Al-Sahih Al-Mukhtasar, Damascus: Dar Ibn Katheer, Kitab Al-Mathalem Wa Al-Qasb, Bab Itha Ikhtalafu Fi At-Tariq Al-Mayta', Hadith No. 2293. p. 411

${ }^{75}$ At-Tutili (1999), Al-Qada’ Bil Murfaq Fi Al-Mabani Wa Nafi Al-Darar, p. 171

${ }^{76}$ Zaqour (2005), Al-Qawaed Al-Fiqhiyyah, p. 65.

${ }^{77}$ Anette Gangler, Heinz Gaube and Attilio Petruccioli (2004), Bukhara, the Eastern Dome of Islam: Urban Development, Urban Space, Architecture and Population. Stuttgart: Edition Axel Menges, p. 88.

${ }^{78}$ Faedah M. Totah (2014), Preserving the Old City of Damascus, United States: Syracuse University Press, p. 48.

${ }^{79}$ Totah (2014), Preserving the Old City of Damascus, p. 51.
} 
land from the Muslims' ways or courtyards, Allah will encircle his neck down the seven earths." 80 Accordingly, Imam Malik prevented the division of yards and spaces that were in front of houses and beside the alleyways because, "These are public interest for the people, and perhaps the alleyway sometimes becomes full of people and animals, so the rider, walker, or the goods' carrier will incline to those yards." ${ }^{\prime 81}$ Furthermore, the Fuqaha' prevented anyone from setting up shops at those yards. Ibn Habib al-Maliki (238 A.H.) asked Imam Mutrif and Ibn al-Majeshon if it is forbidden for a man to build columns in the alleyway adhering to his wall. They said, "Yes, he does not have the right to narrow the public alleyway even if the alleyway still wide for the pedestrians and wagons." $\$ 2$

The Fuqaha' emphasized the necessity of covering the toilet pit (wing) in the roads, and Imam Sahnoun was asked whether it is prohibited for people to dig pits in the paths near their houses. He replied, "If the pits are covered very well at the same level and do not harm anyone, I do not see the need to prevent them." ${ }^{\prime 3}$ The Fuqaha' of Al-Maliki said, "If a man demolished his house, he should not throw the rubbles in the alleyway as it may hurt the pedestrians." ${ }^{" 84}$ They argued that the demolisher ought to rent a special place to throw the remains (rubbles, dust, dirt and so on) to avoid damaging the roads.

\section{Findings}

Usul Al-Fiqh (Principles of Islamic jurisprudence) are methodological principles used in the Islamic jurisprudence for deriving rulings of Shari'ah (Islamic law). These principles comprise four main methods sorted by priority: Quran, Sunnah, Ijtihad (independent reasoning), and Qiyas (deductive analogy). Based on these principles, the Maliki jurists concluded the provisions and rules related to architecture and built environment, which are realization of benefit and prevention of harm, consideration of public interest over self-seeking interest, committing the lesser of two harms, and arbitration of the Urf (prevailing custom). Depending on these four rules, the researcher divided the factors that influenced the Islamic cities into five categories:

1. Consideration of privacy and sanctity that contributed in formulating the city through the design of houses with courtyards to protect privacy, in addition to the concentration on the centrality of mosques in the city.

2. Preservation of the environment in the city by providing green areas in the houses and public places, and establishing courtyards between the houses to be used as facilities, as well moving the industrial districts out of the city that cause smoke, gas, bad odors, annoying sounds, or wall cracks.

3. Consideration of health conditions in the city, where four points were taken into consideration by the Fuqaha': water and air to be cleaned, enough light to be provided, and a sewage system to be maintained to avoid dirt, odors, and harm.

4. The safety conditions of construction mentioned in Figh Al-Maliki included three topics: roof bearing capacity, wall durability, and balcony cantilever.

5. Road maintenance was managed by the Islamic Fiqh through determinants of the road breadth, giving priority to public ways, and preventing road encroachments.

The researcher summarizes the research findings in the diagram illustrated below:

\footnotetext{
${ }^{80}$ Abu Al-Qasem S. At-Tabarani (1983), Al-Rawd Ad-Dani (Al-mu'jam Al Saghir), Vol. 1, Amman: Al-Maktab Al-Islami (Dar Ammar), volume 2, p. 297.

${ }^{81}$ Al-Hattab (2010), Mawaheb Al-Jalil Fi Sharh Mukhtasar Khalil, p. 155.

${ }^{82}$ At-Tutili (1999), Al-Qada' Bil Murfaq Fi Al-Mabani Wa Nafi Al-Darar, p. 162.

${ }^{83}$ Al-Gharnati (2016), Al-Qawanin Al-Fiqhiyyah, p. 165.

${ }^{84}$ Ibn Ar-Rami (1999), Al-Iklan Fi Ahkam Al-Bunian, p. 80.
} 


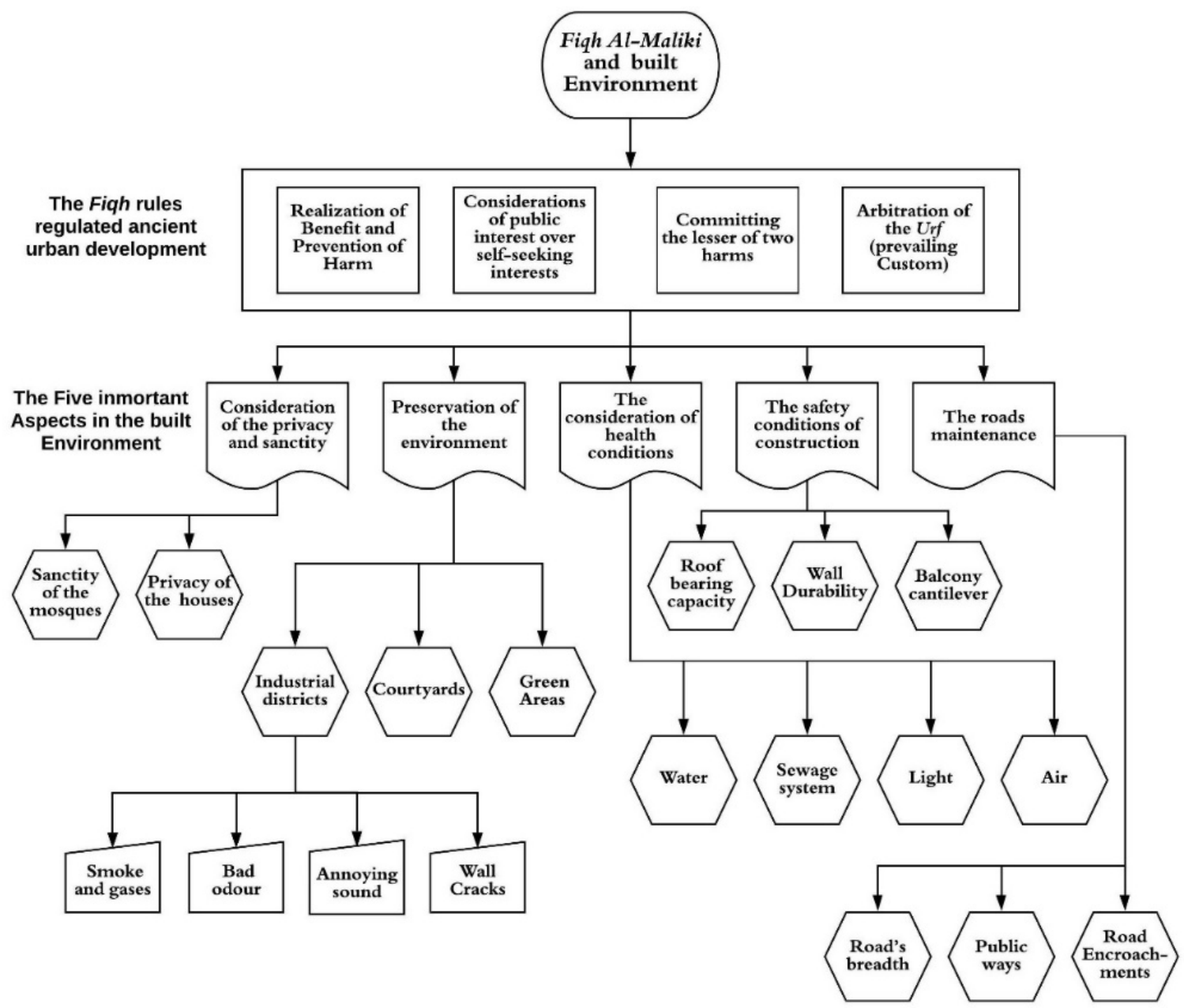

Figure 15: The Points that Fiqh Al-Maliki is Focused on in Terms of Built Environment

\section{Conclusion}

In this research, the researcher revealed the relationship that existed between Islamic Figh and the methods of building the old cities. The results suggest that urban growth in the ancient Islamic cities was mostly subjected to the provisions of Fiqh that regulated the urban development based on the principles of realization of benefit and prevention of harm. These provisions can be summarized into five aspects. The first aspect focused on the consideration for privacy and sanctity. The second aspect was about the preservation of the environment in the city. The third aspect explained the consideration for health conditions in the city. The fourth aspect dealt with the safety conditions of construction in the Islamic Fiqh, while the fifth aspect focused on the Islamic Fiqh and road maintenance.

It can be concluded that there is a strong relationship between the Islamic Fiqh and the built environment, and Fiqh Al-Maliki made significant contributions toward city planning, alleyway organization, building design, and green area preservation. The Fuqaha' from Madhhab Al-Maliki played an important role via their Fatwas that touched on daily structural issues and assisted people in solving several problems before they escalated. Such issues are cumulative and the current Fuqaha' can benefit from such issues to maintain the original form of Islamic cities. That being said, the research on the relationship between the Islamic Fiqh and the built environment is still in its early stages. Further in-depth exploration is necessary to invest the results in the development of urban tourism fields based on scientific rules from the Islamic Fiqh heritage.

\section{References}

Abbah, Mohammad W. (2011), Madkhal Ila Usul Al-Fiqh Al-Maliki, Morocco: Dar Al-Aman.

Al-Abdary, Abu A. (1994), At-Taj Wa Al-Iklil Fi Sharh Mukhtasar Ash-Shiekh Khalil, Beirut: Dar AlKutub Al-Ilmiyah. 
Al-Bukhari, Mohammad I. (2013), Sahih Al-Bukhari, Aw, Al-jami' Al-Sahih Al-Mukhtasar, Damascus: Dar Ibn Katheer.

Al-Dosary, Adel A. (2014), Principles For The Rejuvenation Of An Islamic City In The Modern Context: The Case Of Medina Of Tunis, Italy: EDUCatt Università Cattolica.

Al-Dosouqi, Mohammad A. (2016), Hashiat Al Dusooki Al Al Shareh Al Kabir V4, Lebanon: Dar El Fikr for Printing publishing and distribution (S.A.L.).

Al-Hanbali, Abu Al-Fath A. (2013), Al-Matla'a Ala Abwab Al-Muqne'a, Saudi Arabia: Al-Maktab AlIslami.

Al-Hasani, Sayyid M. (2005), Fiqh Keluarga: Seni Berkeluarga Islami, Indonesia: Bina Media.

Al-Hattab, Mohammad M. (2010), Mawaheb Al-Jalil Fi Sharh Mukhtasar Khalil, Jordan: Dar Al Radwan.

Al-Mazari, Abi Abdul Rahman O. (2015), Sharh At-Talqen Fi Al-Figh Al-Maliki Le Al-Qadi AlBaghdadi, Lebanon: Dar Al Kotob Al Ilmiyah.

Al-Qanouji, Siddiq B. (1978), Abjad Al-Ulum, Syria: Ministry of Culture \& Dar Al-Kutub Al-Ilmiyah. Al-Gharnati, Ibn Juzayy M. (2016), Al-Qawanin Al-Fiqhiyyah, Beirut: Dar Al-Kutub Al-Ilmiyyah.

Al-Qurafi, Shebuddin A. (1994), Ath-Thakhirah, Beirut: Dar Al-Gharb Al-Islami.

Anas, Malek B. (2018), Muwatta Imam Malik, Aleppo: Dar Ihya'a At-Turath Al-Arabi

Ar-Razzi, Muhammed A. (1999), Mukhtar As-Sihah, Vol. 5, Saida: Al-Maktabah Al-Asriyah AnNamothajiyyah.

Ibn Ar-Rami, Ahmad A. (1999), Al-Iklan Fi Ahkam Al-Bunian, Ishbiliyah: Media and research center.

As-Sanhouri, Abi An-Naja S. (2019), Tayseer Al-Malik Al-Jalil Le Jama' Al-Shorouh Wa Hawashi Khalil Fi Al-Fiqh Al-Maliki, Lebanon: Dar Al Kotob Al Ilmiyah.

At-Tabarani, Abu Al-Qasem S. (1983), Al-Rawd Ad-Dani (Al-mu'jam Al Saghir), Vol. 1, Amman: AlMaktab Al-Islami (Dar Ammar).

Al-Jurjani Ali M. (2011), At-Tareefat, Egypt: Sar Ar-Rayyan Le At-Turath.

At-Tutili, Issa M. (1999). Al-Qada' Bil Murfaq Fi Al-Mabani Wa Nafi Al-Darar, Rabat: Islamic Educational, Scientific and Cultural Organization (ISESCO).

At-Tulaitili, Ahmad M. (2000), Al-Muqnea' Fi Ilm Al-Shorout, Lebanon: Dar Al-Kotob Al-Ilmiyyah.

Baderin, Mashood A. (2017), Islamic Legal Theory (Usūl Al-Fiqh), Vol. 1, London: Taylor \& Francis.

Bianca, StefaNo. (2000), Urban Form in the Arab World: Past and Present, United Kingdom: Thames \& Hudson.

Brockopp, Jonathan. (2000), Early Maliki Law: Ibn 'Abd Al-Hakam and His Major Compendium of Jurisprudence, Netherlands: Brill Publishers.

Gangler, Anette. Gaube, Heinz. and Petruccioli, Attilio (2004), Bukhara, the Eastern Dome of Islam: Urban Development, Urban Space, Architecture and Population, Stuttgart: Edition Axel Menges. 
Hakim, Besim S. (2001), "Reviving the rule system. An approach for revitalizing traditional towns in Mahgrib," Cities, Vol. 18, No. 2, 87-92

Jazaeri, Basher A. (2008), Usul wa Furu' fi Al-Mashreq Al-Arabi Qadem wa Hadith: Masader Al-Fiqh Al-Maliki, Msaytbeh: Dar Ibn Hazm.

Koh, Eunsook and Owen, Willis (2000), "Descriptive Research and Qualitative Research," in Introduction to Nutrition and Health Research, Boston: Springer.

Kutluay, Ibrahim (2011), "The meaning and scope of Sunnah according to Imam Mālik and the practice of the people of Medina," Energy Education Science and Technology Part B: Social and Educational Studies, Vol. 3, No. 3, 359-368.

Motzki, Harald (2002), The Origins of Islamic Jurisprudence: Meccan Fiqh Before the Classical Schools, Netherlands: Brill Publishers.

Omer, Spahic (2009), Islam, Architecture and Urban Planning, Malaysia: Arah Pendidikan Sdn Bhd.

Peters, Lucas (2017), Moon Morocco, New York: Avalon Publishing.

Qoqani, Abdul Hafiz F. and Salih, Muhammad I. (1999), The Islamic jurisprudence about mosque architecture, Kingdom of Saudi Arabia: King Saud University.

Quesada, Juan M. (2005), El mundo jurídico en Al-Andalus, Spain: Delta Publicaciones Universitarias.

Raysouni, Qutub (2008), Nawazel Ahmad Bin Saeed Bin Bashtaqeer Al-Lawraqi Al-Maliki, Beirut: Dar Ibn Hazm.

Riaz, Hassan (2018), "Religion, Modernization And The Islamic Ummah," Journal of Al-Tamaddun, Vol. 13, No. 1, 57-64.

Roberson, Barbara A. (2013), Shaping the Current Islamic Reformation, London: Frank Cass.

Sahnun, Ibn Saed A. (2005), Al-Mudawwana Al-Kubra lil Imam Malik Ibn Anas, United Arab Emarates: Dar Sader.

Salih, Muhammad I. and Qoqani, Abdul Hafiz F. (1999), The urban design of mosques, Kuwait: The Ministry of Higher Education in Collaboration with the Ministry of Islamic Affairs.

Shakour, Adel A. and Iwaidah, Salah (2010), Hashiyat Ash-Shaikh Ibrahim Al-Baijouri Ala Sharh AlAllamah Aby Al-Qasem, Cairo: Shorouk International Bookshop.

Soltanzadeh, Hossein and Moghaddam, Mohammadreza Sadeghi (2015), "Sana'a, Structure, Historical Form, Architecture and Culture," Civil Engineering and Architecture, Vol. 3, No. 3, 56-67.

Tahir, Hailani M. (2019), The Conceptual Idea of the Mua 'Malat Fiqh Forensic in the Islamic Financial System, Singapore: Partridge Publishing Singapore.

The Arab League Educational, Cultural and Scientific Organization (2004), Mawsua'at A'alam AlUlama' Wa Al-Udabaa' Al-Arab Wa Al-Muslimin, Lebanon: Dar Al-Jil.

Totah, Faedah M. (2014), Preserving the Old City of Damascus, United States: Syracuse University Press.

Verskin, A. (2013), "The Evolution of the Maliki Jurists' Attitudes to the Mudejar Leadership," Der Islam, Vol. 90, No. 1, 44-64 
Journal of Al-Tamaddun, Vol. 15 (2), 2020, 81-94

Wazire, Yahaya (2004), Islamic Architecture and Environment, Kuwait: National Council for Culture, Arts and Letters.

Waziri, Yahya (1999), Mawsu'ah 'anasir al-'imarah al-Islamiyah, Egypt: Maktabah Madbuli.

Ya'amuri Ibn Farhoun I. (1996), Al-Debaj Al-Muthahhab Fi Tarajim A'ayan Al-Mathhab, Lebanon: Dar Al-Kotob Al-Ilmiyyah.

Zaqour, Ihsan (2005), Al-Qawaed Al-Fiqhiyyah Al-Mustanbatah Min Al-Mudawanah Al-Kubra Lel Imam Malik, Lebanon: Dar Ibn Hazm. 